DOI: $10.5277 /$ epe 160209

\title{
COMPOSTING AND ANAEROBIC DIGESTION TECHNOLOGIES AS METHODS FOR REDUCTION OF VIRUS TRANSMISSION IN THE ENVIRONMENT
}

\begin{abstract}
Survival of bovine enterovirus was studied in animal by-products subjected to sanitization processes. Composting technology and anaerobic digestion under mesophilic $\left(37^{\circ} \mathrm{C}\right)$ and thermophilic $\left(55^{\circ} \mathrm{C}\right)$ conditions were tested in terms of their effectiveness. Viruses were introduced into the biomass in the course of waste treatment processes and virus titres were determined at appropriate time intervals. Technology which allowed the most effective virus elimination, after $2 \mathrm{~h}$, was thermophilic fermentation. During composting, bovine enterovirus survival ranged from 12 to 17 days, whereas the survival time for mesophilic fermentation was 28 days.
\end{abstract}

\section{INTRODUCTION}

Bovine enterovirus (BEV) is characterized by high environmental stability. It is relatively resistant both to chemical and physical factors [1]. Although it belongs to the same group as the foot and mouth disease virus, it is not pathogenic for people and often serves as a model for determination of the survival rate of other viruses [2]. In the literature, one can find papers on effectiveness of slurry and sewage sludge sanitization based on a degree of inactivation of bovine enterovirus [3]. Nevertheless, there are only few studies concerning BEV behaviour in organic wastes processed with biotechnological methods [4]. Viruses introduced into the environment along with untreated organic wastes may survive in soil for several weeks $[5,6]$. The objective of the study was to determine applicability of the bovine enterovirus as an indicator of effectiveness of biotechnological methods for disposal of meat waste. Physicochemical properties of the virus are similar to other viruses. Therefore, the rate of its inactivation may be a measure

${ }^{1}$ Department of Microbiology and Food Technology, University of Technology and Life Science, ul. Bernardyńska 6/8, 85-029 Bydgoszcz, Poland, corresponding author Z. Paluszak, e-mail: paluszak@utp.edu.pl

${ }^{2}$ Department of Virology, National Institute of Hygiene, ul. Chocimska 24, 00-791 Warsaw, Poland. 
of inactivation of other viruses with similar properties, present in the biomass. It is notable that bovine enterovirus is virtually not identified in our country, although known to be very common and isolatable from animals showing no symptoms of the disease. Hence, the virus is very likely to occur in a slurry not subject to sanitary control and used for co-fermentation processes with meat wastes.

This study is devoted to the BEV behaviour in the meat wastes subjected to various biological processes aiming at the waste treatment for agricultural purposes. Three technologies of sanitization of organic waste were tested in the study in terms of their effectiveness in elimination of bovine virus: composting in a bioreactor, digestion in mesophilic conditions and in thermophilic conditions on a semi-technical scale in an experimental bioreactor.

\section{EXPERIMETAL}

A rotating-drum composter (EcoPro, Masstech) was used for composting meat wastes $(60 \%)$ and sawdust $(40 \%)$. Anaerobic digestion of animal by-products under mesophilic conditions was performed at $37{ }^{\circ} \mathrm{C}$ in the agricultural biogas board (Poldanor S.A.) and under thermophilic conditions at $55^{\circ} \mathrm{C}$ in an experimental minireactor. Viruses, either adsorbed on filters or as a suspension in Eppendorf tubes, were placed in meat carriers of various degree of fragmentation (minced, $3 \times 3 \times 3 \mathrm{~cm}$ and $5 \times 5 \times 5 \mathrm{~cm}$ cubes), in bone carriers, or introduced directly into the biomass (Figs. 1,2). The carriers were removed at appropriate time intervals and virus titres were determined.
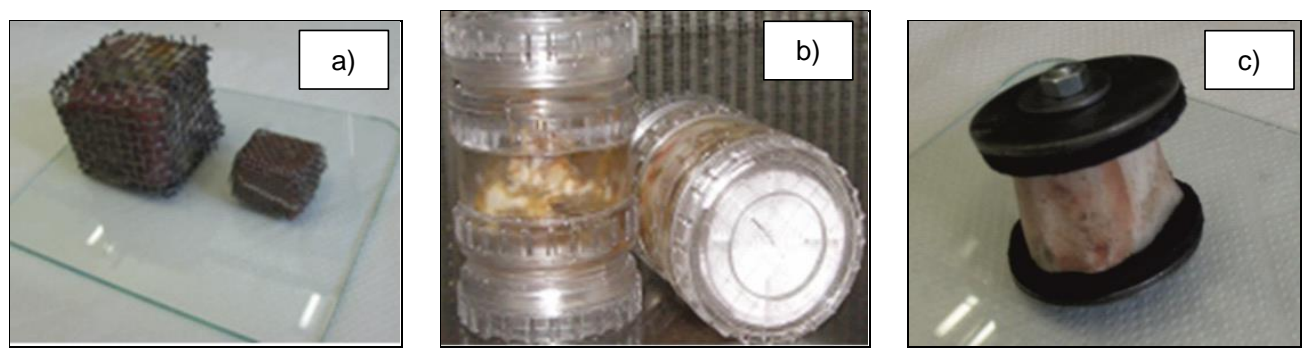

Fig. 1. Meat carriers (a), carriers with minced meat (b) and a bone carrier - femoral shaft (c)

Bovine enterovirus BEV, strain LCR-4 from the collection of the Institute of Animal Hygiene, University Hohenheim in Stuttgart, was used for this study. Viruses were multiplied on MDBK cell line (Madin and Darby Bovin Kidney), using Eagle's liquid without serum with antibiotics added (penicillin, streptomycin, mycostatin). Multiplied MDBK cells were infected with LCR-4 at a dose of $2-4$ TCID $_{50}(50 \%$ tissue culture 
infectious dose) per cell. After 3 freeze and thaw cycles, the culture was centrifuged to give the virus pool with a titre of about $10^{6} \mathrm{TCID} \mathrm{D}_{50} / \mathrm{cm}^{3}$. Virus adsorption on filters was according to the Filter-Sandwich method [7]. $1 \mathrm{~cm}^{3}$ of viral suspension in phosphate buffer, pH 6.5 was placed on a nylon membrane Zetapor (Cuno, Inc., Meriden, Conn., U.S.A., 64085-01-1 MDS) $500 \mu \mathrm{m}$ thick with $10 \mathrm{~nm}$ pores. Virus containing carriers were placed in polycarbon sacks with $0.015 \mu \mathrm{m}$ pore diameter (Infiltec $\mathrm{GmbH}$, Polycarbonatmembran, type PC-KN1CP81030) in order to prevent viral particles from penetrating outside the carrier (Fig. 2).

Fig. 2. Virological carrier - filter

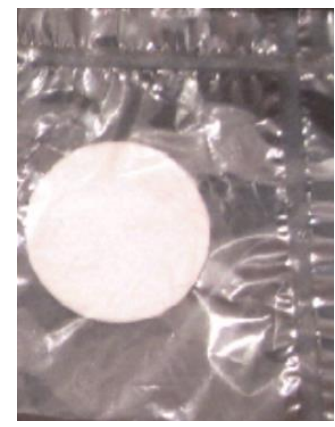

Carriers were removed at appropriate time intervals and virus titres were determined. Virus titre analyses were performed on an MDBK cell line by the microplate method. Logarithmic dilutions $\left(10^{-4}-10^{-8}\right)$ of strain suspensions in the Eagle's liquid were made. $0.05 \mathrm{~cm}^{3}$ of suitably diluted viral suspension, $0.05 \mathrm{~cm}^{3}$ of Eagle's liquid and $0.1 \mathrm{~cm}^{3}$ of MDBK cell suspension were added to each of 4 hollows. Microplates were incubated at $5 \% \mathrm{CO}_{2}$ at $37^{\circ} \mathrm{C}$. Infected colonies could be observed on the 4th and 5th day under the inverted microscope. The titres were calculated with the Kärber method [8] and presented as $\mathrm{TCID}_{50} / \mathrm{cm}^{3}$ of the final eluate volume.

\section{RESULTS}

The temperature of the biomass in the composter oscillated around $50{ }^{\circ} \mathrm{C}$ for the most part of the process. At about 60th hour of the cycle, temperature increased up to $60{ }^{\circ} \mathrm{C}$ and remained at this level for about $12 \mathrm{~h}$. Afterwards, the maximum temperature of $62.9^{\circ} \mathrm{C}$ was obtained (Fig. 3).

The fastest virus inactivation was demonstrated for particles adsorbed on filters and placed in the bone shaft, since as early as the 100th hour of the process the titre decreased below $1.55 \mathrm{TCID}{ }_{50} / \mathrm{cm}^{3}$. Therefore, regression lines could not be calculated (Tables 1,2). The longest virus survival time was achieved for the suspension introduced into the biomass in Eppendorf tubes. 


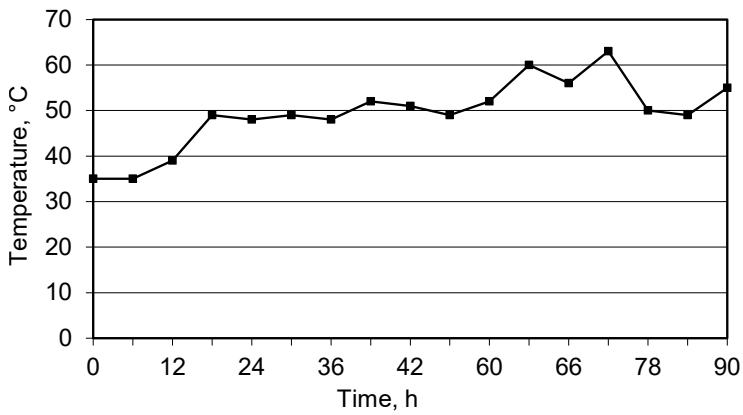

Fig. 3. Course of temperature during the composting process

Table 1

Average BEV titres $\left[\log \mathrm{TCID}_{50} / \mathrm{cm}^{3}\right]$ in various types of carriers during the composting process

\begin{tabular}{|l|c|c|c|c|c|}
\hline \multirow{2}{*}{\multicolumn{1}{|c|}{ Type of carrier }} & \multicolumn{5}{|c|}{ Time [h] } \\
\cline { 2 - 6 } & 0 & 60 & 100 & 112 & 210 \\
\hline Filter in the bone shaft & 5.8 & 3.8 & $<1.55$ & $<1.55$ & $\mathrm{nt}$ \\
\hline Filter in the meat cube $(5 \times 5 \times 5 \mathrm{~cm})$ & 5.8 & 4.05 & 3.8 & 3.55 & $\mathrm{nt}$ \\
\hline Eppendorf tube in biomass & 5.8 & 5.8 & 4.8 & 4.4 & 2.8 \\
\hline
\end{tabular}

nt - not tested

Table 2

Equations of regression lines describing BEV inactivation rate during the composting process

\begin{tabular}{|l|c|c|c|}
\hline \multicolumn{1}{|c|}{ Type of carrier } & $\begin{array}{c}\text { Regression } \\
\text { equation }\end{array}$ & $\begin{array}{c}\text { Total virus } \\
\text { survival time }\end{array}$ & $\begin{array}{c}\text { Decrease } \\
\text { in virus titre } \\
{[\log / \text { hour }]}\end{array}$ \\
\hline Filter in meat cube $(5 \times 5 \times 5 \mathrm{~cm})$ & $y=-0.019 x+5.62$ & $288.4 \mathrm{~h}(12$ days $)$ & 0.019 \\
\hline Eppendorf tube in biomass & $y=-0.015 x+6.20$ & $402.9 \mathrm{~h}(16.8$ days $)$ & 0.015 \\
\hline
\end{tabular}

Table 3

Average BEV titres $\left[\mathrm{TCID}_{50} / \mathrm{cm}^{3}\right]$ and regression equations describing virus inactivation rate during mesophilic digestion $\left(37^{\circ} \mathrm{C}\right)$

\begin{tabular}{|c|c|c|c|c|c|c|c|c|}
\hline \multirow{2}{*}{$\begin{array}{l}\text { Type of } \\
\text { carrier }\end{array}$} & \multicolumn{5}{|c|}{ Time [days] } & \multirow{2}{*}{$\begin{array}{c}\text { Regression } \\
\text { equation }\end{array}$} & \multirow{2}{*}{$\begin{array}{c}\text { Total virus } \\
\text { survival time } \\
\text { [days] }\end{array}$} & \multirow{2}{*}{$\begin{array}{c}\text { Decrease } \\
\text { in virus titre } \\
{[\log / \text { day }]}\end{array}$} \\
\hline & 0 & 7 & 14 & 21 & 28 & & & \\
\hline $\begin{array}{l}\text { Eppendorf tube } \\
\text { in biomass }\end{array}$ & 6.05 & 3.1 & 2.05 & 2.1 & $<1.55$ & $y=-0.187 x+5.28$ & $x=28.2$ & 0.187 \\
\hline
\end{tabular}


During mesophilic digestion, the survival of viruses was analysed in one type of carrier only - an Eppendorf tube. The titre decreased by $4 \log$ during the first three weeks, whereas viable viral particles were not detected on the 28 th day of the study (Table 3). According to the regression line, the total BEV survival time was 28.2 days.

Table 4

Average BEV titres [TCID $50 / \mathrm{cm}^{3}$ ] in various types of carriers during thermophilic digestion $\left(55^{\circ} \mathrm{C}\right)$

\begin{tabular}{|l|c|c|c|c|}
\hline \multirow{2}{*}{ Carrier } & \multicolumn{4}{|c|}{ Time [min] } \\
\cline { 2 - 5 } & 0 & 15 & 60 & 90 \\
\hline Minced meat & 6.05 & 6.05 & 5.3 & $<1.55$ \\
\hline Meat cube $(3 \times 3 \times 3 \mathrm{~cm})$ & 6.05 & 5.8 & 4.05 & $<1.55$ \\
\hline Meat cube $(5 \times 5 \times 5 \mathrm{~cm})$ & 6.05 & 6.05 & 4.55 & $<1.55$ \\
\hline Bone shaft & 6.05 & 6.05 & 5.8 & $<1.55$ \\
\hline Biomass & 6.05 & 5.8 & 5.3 & $<1.55$ \\
\hline
\end{tabular}

A very fast decrease in virus titres was observed in all the carriers used for thermophilic digestion. As early as the 90th minute of the process active particles were detected in none of the carriers. The inactivation was the fastest in the $3 \times 3 \times 3 \mathrm{~cm}$ meat cubes, whereas the slowest - in the bone shaft and minced meat (Table 4). The total virus survival time oscillated within the range of about 103 and $113 \mathrm{~min}$, while a decrease in the virus titre was similar in all the carriers amounting to ca. $0.6 \mathrm{log} / \mathrm{min}$ (Table 5).

Table 5

Regression equations describing BEV inactivation rate during thermophilic digestion $\left(55^{\circ} \mathrm{C}\right)$.

\begin{tabular}{|l|c|c|c|}
\hline \multicolumn{1}{|c|}{ Carrier } & Regression equation & $\begin{array}{c}\text { Total survival time } \\
\text { of virus [min }]\end{array}$ & $\begin{array}{c}\text { Decrease in virus titre } \\
{[\mathrm{log} / \mathrm{min}]}\end{array}$ \\
\hline Minced meat & $y=-0.060 x+6.84$ & 113.2 & 0.060 \\
\hline Meat cube $(3 \times 3 \times 3 \mathrm{~cm})$ & $y=-0.065 x+6.72$ & 103.5 & 0.065 \\
\hline Meat cube $(5 \times 5 \times 5 \mathrm{~cm})$ & $y=-0.063 x+6.77$ & 107.2 & 0.063 \\
\hline Bone shaft & $y=-0.058 x+6.84$ & 117.7 & 0.058 \\
\hline Biomass & $y=-0.060 x+6.84$ & 113.2 & 0.060 \\
\hline
\end{tabular}

\section{DISCUSSION}

Improperly conducted sanitization of organic wastes, including inedible meat wastes, may lead to formation of products which are dangerous for the natural environment. Their application in fertilization can contribute to water, soil and plant pollution. Viruses that are introduced into the environment with organic fertilizers can be adsorbed 
on soil particles and then transported into deeper soil layers. It is estimated that they can survive from 150 to 170 days there, depending on the species [9].

If properly carried out with the thermophilic phase lasting long enough, the composting process of meat wastes should ensure obtaining a safe product in terms of sanitation. High temperature of the composted material seems to be the main factor causing the virus inactivation. In the event of biomass heating up to $60-70{ }^{\circ} \mathrm{C}$ as a result of thermophilic treatment, the elimination of enterovirus or thermoresistant bovine parvovirus in composted biological wastes takes several days [10-12]. Winter [4] observed during the intensive composting of rumen content a decrease in BEV titre from 4.7log to the limit of detection after $12 \mathrm{~h}$ at $60{ }^{\circ} \mathrm{C}$. Also, at this temperature, a decrease in ER virus titre by $4 \log$ occurred after $4-8 \mathrm{~h}$, while for the thermoresistant BPV - by $6.1 \log$ not earlier than after 20-28 h. Monteith et al. [11] subjected cattle manure to composting for 28 days and the biomass temperature from the 3rd day until the end of the experiment remained at the level of $60^{\circ} \mathrm{C}$. After that time, viable BEV was not detected. In the present study, the temperature inside the composter oscillated within the range of $50-60{ }^{\circ} \mathrm{C}$ for the most part of the process and the highest values remained steady for about $12 \mathrm{~h}$. Such conditions were sufficient for inactivation of the tested viruses after 12-17 days (depending on the carrier type). The viruses adsorbed on membrane filters and placed in the bone shaft underwent the fastest inactivation; a decrease in the titre from 5.8 to the detection limit occurred after $100 \mathrm{~h}$. The total virus survival time, almost 17 days, was the longest for the suspension in the Eppendorf tube, the same not in contact with chemical agents generated in the process.

Studies by Winter [4] reflect the temperature effect on the inactivation of virus in the composted biomass. BEV elimination after $1 \mathrm{~h}$ was observed after increase of temperature up to $67^{\circ} \mathrm{C}$, whereas in the biomass heated to $48^{\circ} \mathrm{C}$ a decrease in the virus titre was slower and ranged from 1.5 to $2.5 \log$ after $2 \mathrm{~h}$. Further reduction in temperature to $46.5^{\circ} \mathrm{C}$ considerably prolonged the virus survival time and 4-log decrease was achieved not earlier than after $40 \mathrm{~h}$.

It is worth noting that, in relation to other carriers, a fall in the virus titre was faster by $1.4 \mathrm{log}$ in carriers facilitating contact of viruses with the environment (membranes with pores). The present study demonstrated a similar relationship - viruses in Eppendorf tubes were eliminated considerably slower than filter-adsorbed. It is worth noting that virus elimination under mesophilic conditions often is equally effective as the thermophilic one. Winter [4] reports that in some compost piles BEV elimination rate within the range of $45-46{ }^{\circ} \mathrm{C}$ is similar to that at $56{ }^{\circ} \mathrm{C}$. It seems that beside temperature, biomass drying, liberated ammonia, biomass density and the antagonistic effect of native microflora can significantly influence the process of virus elimination under mesophilic conditions [13].

Also in anaerobic digestion, the virus elimination rate is closely correlated with temperature. According to Bierman [14], under psychrophylic conditions at $4{ }^{\circ} \mathrm{C}$, the enterovirus count decreased after 26 weeks by $1 \log$ only, whereas at $31{ }^{\circ} \mathrm{C}$ the count 
fell by $6.25 \log$ after 9 days [3]. The enterovirus survival in anaerobic mesophilic conditions varies. Derbyshire [15] showed that the swine enterovirus underwent continuous elimination at $35{ }^{\circ} \mathrm{C}$ but it was not fully inactivated. However, other authors still could detect the enterovirus on the 13th day of the fermentation process [11]. In the present study, viable BEV could still be isolated on the 21st day of the process. However, a considerably slower reduction in the virus titre of about $0.2 \mathrm{log} /$ day was also observed and the total survival time was calculated at 28 days. Longer survival in relation to the results of other authors could result from a protective action of tube walls against chemical agents, which play essential role in pathogen elimination during mesophilic digestion.

Under thermophilic conditions, the process of virus elimination is considerably faster. Lund et al. [16] found a minimum guaranteed retention time (MGRT) for bovine enterovirus to be $23 \mathrm{~h}$ at mesophilic temperatures compared to less than $0.5 \mathrm{~h}$ under thermophilic conditions. Similar results by Martens et al. [3] showed that at $54.5{ }^{\circ} \mathrm{C}$ bovine enteroviruses, adsorbed on filters and introduced into a slurry, survive for several hours only, while at $31{ }^{\circ} \mathrm{C}$ ca. 6 days. In the present study, the average virus survival during thermophilic digestion in all the carriers was within the range 103-117 h. The bone provided the best protection against physicochemical factors, the same allowing the longest survival time.

The presented results fully justify the choice of bovine enterovirus as a model microorganism for the determination of sanitization effectiveness of composting and anaerobic digestion technologies under mesophilic and thermophilic conditions.

\section{CONCLUSIONS}

Meat waste is rich in organic matter which determines its manurial value. Yet the same it may constitute an important ecological problem due to its high pathogenic, including viral, content. In the present study, survival of bovine enterovirus in animal waste subjected to sanitization processes was estimated. The effectiveness of composting technology and anaerobic digestion under meso- and thermophilic conditions was tested. The viruses were adsorbed on filter membranes and introduced into special carriers, i.e. pieces of meat and bones imitating animal wastes, or as a suspension in Eppendorf tubes placed inside meat and bone carriers as well as directly in the waste biomass. BEV titres were estimated every $10-20 \mathrm{~h}$ in the composting experiment, every week during mesophilic fermentation or every 10-20 min during thermophilic fermentation. During composting, the membrane-adsorbed viruses underwent the quickest inactivation in the bone carriers (could not be detected as early as in the 100th hour of the process), whereas the slowest inactivation was recorded for the viruses in suspension in Eppendorf tubes (ca. 17 days). Similarly, mesophilic digestion at $37{ }^{\circ} \mathrm{C}$ did not result in a fast virus inactivation as they survived for 28 days. Digestion in thermophilic conditions demonstrated the highest effectiveness of sanitization. The temperature of $55^{\circ} \mathrm{C}$ 
ensured the inactivation of BEV as early as in the 90th min of the process in each of the carriers. The conclusion is that the bovine virus may be used as a model microorganism for the determination of sanitization effectiveness of different technologies.

\section{REFERENCES}

[1] WeKERle J., Albrecht H., Inactivation of vaccinia virus and a bovine enterovirus in aerated pig slurry with special regard to $\mathrm{pH}$, temperature and free ammonia modification during aeration, Agr. Wastes, 1983, 7 (1), 39.

[2] MAYr M., Rolle A., Medizinische Mikrobiologie, Infektions- und Seuchenlehre, Ferdinand Enke Verlag, Stuttgart 1984.

[3] Martens M., Fink A., PhilipP W., Weber A., Winter D., BöHm R., Seuchenhygienische Bewertung von Anaerobverfahren. Tagungsband zum 7. Hohenheimer Seminar: Biologische Abfallbehandlungerste Erfahrungen mit der Bioabfallverordnung in Deutschland, 29-31 März 1999, Universität Hohenheim, 1999, 150.

[4] WINTER D., Virologische Untersuchungen zur Überprüfung von Gulle-Aufbereitungsverfahren und der erzeugten Gulle-Aufbereitungsprodukte unter den Aspekten der Veterinar- und Seuchehygiene, Thesis, Universität Hohenheim, 2002.

[5] Olszewska H., Paluszak Z., JarZąBeK Z., Survival of bovine enterovirus strain LCR-4 in water, slurry and soil, Bull. Vet. Inst. Puławy, 2008, 52 (2), 205.

[6] Vasickova P., Dvorska L., Lorencova A., Pavlik I., Viruses as a cause of foodborne diseases. A review of the literature, Vet. Med.-Czech., 2005, 50 (3), 89.

[7] Traub F., SPILlmann S.K., WYLER R., Method for determining virus inactivation during sludge treatment processes, Appl. Environ. Microbiol., 1986, 52 (3), 498.

[8] KÄRBER G., Beitrag zur kollektiven Behandlung pharmakologischer Reihenversuche, Arch. Exp. Pathol. Pharmacol., 1931, 162, 480.

[9] KeLly W.R., Animal and human health hazards associated with the utilization of animal effluents, Commission of the European Communities, EUR 6009 EN, ESCS-EECEAEC, Brussels 1978.

[10] Feachem R.G., Bradley D.J., Garelick H., Mara D.D., Sanitation and Disease. Health Aspects of Excreta and Wastewater Management, Wiley, Chichester 1983.

[11] Monteith H.D., SHANNON E.E., The inactivation of bovine enterovirus and a bovine parvovirus in cattle manure by anaerobic digestion, heat treatment, gamma irradiation, ensilage and composting, J. Hyg. Camb., 1986, 97 (1), 175.

[12] Paluszak Z., Lipowski A., Ligocka A., Survival of BPV and Aujeszky's disease viruses in meat wastes subjected to different sanitization processes, Pol. J. Vet. Sci., 2010, 13 (4), 749.

[13] Deng M.Y., Cliver D.O., Antiviral effects of bacteria isolated from manure, Microb. Ecology, 1995, $30(1), 43$.

[14] BIERMANN U., HeRbST W., SCHLIESSER T., The persistence of bovine enterovirus and pseudorabies virus in liquid cattle manure at different storage temperatures, Berl. Munch. Tierarztl. Wochenschr., 1990, 103 (3), 88.

[15] DerbyshiRe J.B., Monteith H.D., Shannon E.E., Virological studies on an anaerobic digestion system for liquid pig manure, Agr. Wastes, 1986, 18 (4), 309.

[16] LUND B., JENSEN V.F., HAVE P., AHRING B., Inactivation of virus during anaerobic digestion of manure in laboratory scale biogas reactors, Anton. Leeuw., 1996, 69 (1), 25. 